
article, distributed under the terms of the Creative Commons Attribution licence (http://creativecommons. org/licenses/by/4.0/), which permits unrestricted re-use, distribution, and reproduction in any medium, provided the original work is properly cited. The written permission of Cambridge University Press must be obtained for commercial re-use or in order to create a derivative work.

doi:10.1017/S2045381719000200

\title{
Political insurance for the (relative) poor: How liberal constitutionalism could resist plutocracy
}

\author{
T A R U N A B H K H A I T A N *(D) \\ Wadham College, University of Oxford, Parks Road, Oxford OX1 3PN (UK). Melbourne Law School, \\ 185 Pelham St, Carlton, Victoria 3053 (Australia).
}

Email: tarunabh.khaitan@law.ox.ac.uk; t.khaitan@unimelb.edu.au

\begin{abstract}
Fair value of equal political liberties is a key precondition for the legitimacy of a regime in liberal thought. This liberal guarantee is breached whenever a group is permanently or semi-permanently locked out of power. Given the convertibility, subtlety, and resilience of power, gross material inequality produced by neoliberal economic policies - effectively locks the relative poor out of political power. Such lockout breaches the legitimacy constraint on a liberal constitutional democracy. Neoliberal democracies, sooner or later, become plutocracies. This possibility should concern not only liberal political theory but also liberal constitutionalism. The usual objections to a constitutional concern with gross inequality and plutocracy - based on concerns relating to transparency, counter-majoritarianism and flexibility - are useful design instructions, but do not rule out the constitutionalisation of egalitarian and anti-plutocratic norms. A whole panoply of legal and political constitutional measures - already familiar to or incrementally developed from liberal constitutional thought and practice worldwide could be marshalled to effectively promote material equality and resist plutocracy. These measures - documented to map the possibilities rather than as a manifesto seek either to prevent material inequality from becoming excessive or to prevent its conversion into political inequality. Good constitutional design, depending on the context, is likely to deploy several tools from both these toolboxes.
\end{abstract}

Keywords: democracy; equality; fair political opportunity; liberalism; plutocracy

Laissez-faire capitalism ... secures only formal equality and rejects ... the fair value of the equal political liberties ... Welfare-state capitalism also rejects the fair value of the political liberties...

$$
\text { - John Rawls }{ }^{1}
$$

* Professor of Public Law and Legal Theory at University of Oxford, and Future Fellow at University of Melbourne.

1 J Rawls, Justice as Fairness: A Restatement (Harvard University Press, Cambridge, MA, 2001) 137-8. 


\section{Introduction}

Liberal-democratic constitutional discourse has failed the poor. Not so much those who are poor in an absolute sense, i.e. those who lack reasonable access to basic human needs such as food, security, water, shelter, education and warmth. ${ }^{2}$ Whatever their lot in the practice of liberal states, at the discursive level several mainstream liberal theories have consistently held that the satisfaction of these needs is a fundamental, non-negotiable, task of the state.

Liberal constitutionalism has simultaneously developed a rich welfare-capitalist discourse on minimum social rights, even though the practice of some states continues to lag behind in realising these minimum guarantees. The people that this discourse has failed are those who suffer from relative poverty, i.e. those who suffer (income and wealth) poverty in comparison with their richer compatriots. In societies that have a population living in absolute poverty, they would probably also qualify as a subset of the relatively poor. But my main concern here is with societies that have a substantial difference between its highest earners and its lowest, even if the basic needs of those at the lower end of the spectrum are met. There are numerous ways of computing relative poverty, all of them controversial. UNDP's Human Development Reports, for example, use the income quintile ratio: a ratio of the average income of the richest 20 per cent of the population to the average income of the poorest 20 per cent of that population. ${ }^{3}$ Drawing inspiration from UNDP and extending its ratio to include wealth disparities, I will use the term 'poor' in this article to roughly refer to the bottom 20 per cent of a population based on income and wealth. ${ }^{4}$ This bottom 20 per cent group will, in many societies, also suffer from absolute poverty, but in some cases it may not. In some societies, they may mostly be unemployed, in others most of them may

2 There can be, and is, a debate on the list of basic needs whose non-satisfaction defines (absolute) poverty. See generally 'Global Multidimensional Poverty Index', Oxford Poverty \& Human Development Initiative, available at <https://ophi.org.uk/multidimensional-povertyindex/>; A Sen, 'Equality of What?' in SM McMurrin (ed), The Tanner Lectures on Human Values (Cambridge University Press, Cambridge, MA, 1980); A Sen, Development as Freedom (Alfred Knopf, New York, NY, 1999); MC Nussbaum and A Sen (eds), The Quality of Life (Clarendon Press, Oxford, 1993); MC Nussbaum, Creating Capabilities: The Human Development Approach (Harvard University Press, Cambridge, MA, 2011).

3 'Human Development Reports: Income Quintile Ratio', United Nations Development Programme, available at $<\mathrm{http}: / /$ hdr.undp.org/en/content/income-quintile-ratio $>$.

${ }_{4}$ Measuring wealth differentials is much more difficult than income ratios. Since the main goals of this article are conceptual rather than empirical, this should not worry us here. 
well have jobs. The only issue of relevance to our conceptual purposes is their material power in relation to those at the top of the income and wealth distribution scale in that society.

Many scholars writing on the subject have focussed on the need to empower the 'middle' class or even the 'other 99 percent' to save democracies. ${ }^{5}$ My focus on those at the very bottom of a class hierarchy is deliberate. While reduced political power or the diminishing size of the middle classes may well be a problem for the stability of a liberal democracy, the 'political lockout' of the very poor calls into question the very legitimacy of a liberal order. When a group comprehensively loses any genuine prospects of garnering even a threshold level of political power at least some of the time, it has been 'locked out' of power. We will see shortly why no system where such lockout has happened can legitimately call itself a liberal democracy. ${ }^{6}$ It is this fear of lockout that necessitates 'political insurance' - the notion that constitutions can create mechanisms to guarantee a modicum of political power to groups who face the risk of a lockout. ${ }^{7}$

To be sure, material inequality has long been an obsession of philosophers and economists trying to figure out what a just distribution of a society's resources would entail. Within the liberal tradition, theorists have taken a diverse range of positions on this question: they range from noninterventionist libertarians (including the 'neo-liberals'), ${ }^{8}$ to sufficientarians who demand the satisfaction of everyone's needs up to a sufficiency threshold, ${ }^{9}$ to prioritarians who hold that a distribution policy that prioritises benefitting the worst off alone is just, ${ }^{10}$ to (resource) egalitarians who seek

5 See, for example, G Sitaraman, The Crisis of the Middle-Class Constitution: Why Income Inequality Threatens our Republic (Alfred Knopf, New York, NY, 2017); J Fishkin and W Forbath, 'The Anti-Oligarchy Constitution' (2014) 94(3) Boston University Law Review 669.

6 This claim does not necessarily assume an 'aggregative' view of democracy, i.e. as a system of aggregative individual interests and preferences. Even on 'deliberative' models of democracy, such a group lockout would be a key legitimacy threat. As Pettit rightly says, the 'contrast between deliberating and aggregating should not be taken to suggest that deliberative democracy can avoid being an aggregative democracy': P Pettit, 'The Aggregation Problem for Deliberative Democracy' (unpublished manuscript, 11 April 2015) 1.

7 R Dixon and T Ginsburg, 'The Forms and Limits of Constitutions as Political Insurance' (2017) 15(4) International Journal of Constitutional Law 989.

8 F Hayek, The Constitution of Liberty (University of Chicago Press, Chicago, IL, 1960); F Hayek, The Road to Serfdom (George Routledge \& Sons, London, 1944); R Nozick, Anarchy, State and Utopia (Blackwell, Oxford, 1974).

9 H Frankfurt, 'Equality as a Moral Ideal' (1987) 98(1) Ethics 21; Sen, Development as Freedom (n 2); Nussbaum, Creating Capabilities (n 2); J Raz, The Morality of Freedom (repr., Clarendon Press, Oxford, 1988).

10 D Parfit, 'Equality and Priority' 10(3) Ratio 202; J Rawls, A Theory of Justice (Harvard University Press, Cambridge, MA, 1971). 
some measure of material equality. ${ }^{11}$ Thus, it is not that the liberal discourse in general that has ignored the poor. Its failing lies in its assumption that material equality is a matter for political rather than constitutional discourse.

It is true that theorists within particular constitutional traditions have, especially recently, argued for constitutional solutions to material inequality. ${ }^{12}$ But these arguments have typically drawn upon the specificity of that particular constitution's histories and doctrines, rather than the widely accepted premises of liberal constitutionalism more generally. It is the latter task that this article undertakes. ${ }^{13}$ Towards this conceptual goal, I assume, with Choudhry, that ' $[t]$ he ambition of liberal constitutionalism is that a constitutional order must both be legitimate and must enjoy the allegiance of a sufficient number of its citizens'. ${ }^{14}$ Choudhry's legitimacy constraint requires a constitutional order to be objectively legitimate in accordance with norms of political morality. His stability constraint, on the other hand, is directed towards inquiring into whether citizens subjectively consider their system of governance to be legitimate.

Much of the recent constitutional scholarship on inequality is motivated by the stability worry - that a shrinking and disempowered middle class will lead to the destabilisation of a liberal order. The stability constraint requires that no sufficiently salient group should be locked out of political power permanently or semi-permanently. To put the point differently, every group that has the capacity to destabilise the constitutional settlement must have a real prospect of a share in state power at least some of the time, enough to give it a stake in maintaining the constitutional status quo. ${ }^{15}$ Whether the

11 R Dworkin, 'What is Equality? Part 1: Equality of Welfare' (1981) 10(3) Philosophy and Public Affairs 185; R Dworkin, 'What is Equality? Part 2: Equality of Resources' (1981) 10(4) Philosophy and Public Affairs 283; R Dworkin, Sovereign Virtue: The Theory and Practice of Equality (Harvard University Press, Cambridge, MA, 2002).

12 Sitaraman, The Crisis of the Middle-Class Constitution (n 5); KD Ewing, 'Jeremy Corbyn and the Law of Democracy' (2017) 28(2) King's Law Journal 343; Fishkin and Forbath, 'The Anti-Oligarchy Constitution' (n 5).

13 An insightful, although still largely doctrinal, recent article by Dixon and Suk does consider the problem of material inequality from a comparative constitutional lens; see R Dixon and J Suk, 'Liberal Constitutionalism and Economic Inequality' (2018) 85(2) University of Chicago Law Review 369.

14 S Choudhry, 'Bridging Comparative Politics and Comparative Constitutional Law: Constitutional Design in Divided Societies' in S Choudhry (ed), Constitutional Design for Divided Societies (Oxford University Press, Oxford, 2008) 6.

15 A Przeworski, Democracy and the Market (Cambridge University Press, Cambridge, 1991); S Mittal and BR Weingast, 'Self-Enforcing Constitutions: With an Application to Democratic Stability in America's First Century' (2013) 29(2) Journal of Law, Economics and Organization 278; J Ely, 'Facilitating the Representation of Minorities' in Democracy and Distrust: A Theory of Judicial Review (Harvard University Press, Cambridge, MA, 1980); T Ginsburg, Judicial Review in New Democracies: Constitutional Courts in Asian Cases (Cambridge University Press, Cambridge, 2003). 
middle or the lower class, when disempowered or locked out, poses a threat to the stability of a liberal state is a contextual, empirically testable, issue.

In focussing on the lowest class in a material distribution scale (rather than the middle class), this article is concerned primarily with the legitimacy constraint for liberal regimes. The political exclusion of the poor may well make the regime unstable in some contexts - if so, that would be an additional reason to be concerned. The argument is that political lockout of the relative poor makes a regime illegitimate, and no longer liberal. This claim is based on a key legitimacy constraint within liberal constitutionalism, which Rawls spells out as a guarantee of fair value of the equal political liberties, i.e. 'the worth of the political liberties to all citizens, whatever their social or economic position, must be approximately equal, or at least sufficiently equal, in the sense that everyone has a fair opportunity to bold public office and to influence the outcome of political decisions'. ${ }^{16}$ For brevity, I will call this 'fair political opportunity'. Whatever may be the content of fair political opportunity - and there is indeed some scope for reasonable disagreement here - this much should be uncontroversial: if a set of individuals defined by a common personal characteristic is permanently or semi-permanently locked out of a minimum share in political power, the guarantee of fair political opportunity has been compromised. By liberal lights, political lockout of a defined set of people (hereinafter, a 'group', understood loosely) ${ }^{17}$ makes a regime illegitimate.

I will argue that, under conditions of extreme material inequality, fair political opportunity cannot be satisfied by mere formal equality of votes. Because of the nature of social and economic power, disempowered groups sometimes need to be given a measure of political insurance by constitutions in order to prevent their being locked out of power. ${ }^{18}$ Because political lockout of a group is a constitutional rather than a (mere) policy problem, there is a strong case for liberal constitutions to afford a measure of political insurance to the poor. The fact that liberal constitutional practice has failed to seriously engage with its theoretical demands is a serious failing, by its own lights. ${ }^{19}$

Thus, the challenge that gross inequality (of material resources) poses to the legitimacy constraint of liberal constitutionalism is instrumental, although there may well be other reasons, intrinsic or instrumental, why such

16 J Rawls, Political Liberalism (Columbia University Press, New York, NY, 1993) 327 (emphasis added); see also Rawls, Justice as Fairness (n 1) 148ff.

17 As used in this article, it is not essential that the 'group' in question has a self-conscious sense of identity, or any social coherence. All that is required is that the set is defined by a personal characteristic, which could be race, religion, gender, sexual orientation, class, disability and so on.

18 See generally Dixon and Ginsburg, 'Forms and Limits of Constitutions' (n 7).

19 '[L]iberals were dishonoring the very egalitarian principle that made their view attractive': R Gargarella, The Legal Foundations of Inequality (Cambridge University Press, Cambridge, 2010) 226. 
inequality ought to be of constitutional concern. This anti-plutocratic, liberal rationale for caring about equality can tolerate moderate levels of inequality. It only cares about some notional threshold (albeit undefined), beyond which inequality ought not to rise. As Fukuyama argues, 'many of the negative consequences associated with inequality, whether political or economic, do not arise as a linear function of the degree of inequality ... there is something like a tipping point at which social stratification becomes entrenched'. ${ }^{20}$ Thus, if the arguments in this article are correct, liberalism requires constitutions to guard against extreme material inequality. ${ }^{21}$ Despite being qualified and instrumental, however, the argument in the article is genuinely egalitarian - the mischief identified is gross material inequality that affects societies both rich and poor. In other words, societies with high levels of growth or 'development' are just as - if not more vulnerable to the risk of becoming plutocracies as middle- and low-income countries. On this account, what matters to the legitimacy of liberal constitutionalism is the manner in which the total wealth of a country is distributed internally. In other words, Robert Dahl's question is as pertinent today as it was when he first asked it in 1961: 'In a political system where nearly every adult may vote but where knowledge, wealth, social position, access to officials, and other resources are unequally distributed, who actually governs??22

The argument of this article proceeds as follows: Section II will identify three features of power - its convertibility, subtlety and resilience. These features make it very likely that gross material inequality that leads to material power of the rich over the poor, will result in a political lockout of the poor. Thus, neoliberal democracies, which lead to gross inequality, are forever in danger of becoming plutocracies. ${ }^{23}$ It follows, then, that gross material inequality is a constitutional problem, as it affects the very

${ }^{20}$ F Fukuyama, 'Dealing with Inequality' in F Fukuyama, L Diamond and MF Plattner (eds), Poverty, Inequality, and Democracy (John Hopkins University Press, Baltimore, MD, 2012) 8-9.

21 This threshold level of inequality may vary from society to society. At any rate, determining where the line of acceptable levels of inequality falls is beyond the scope of this article.

22 RA Dahl, Who Governs? Democracy and Power in an American City (Yale University Press, New Haven, CT, 1961) 1.

23 D Harvey, A Brief History of Neoliberalism (Oxford University Press, Oxford, 2005) 2:

\footnotetext{
Neoliberalism is ... a theory of political economic practices that proposes that human wellbeing can best be advanced by liberating entrepreneurial freedoms and skills within an institutional framework characterised by strong private property rights, free markets, and free trade. The role of the state is to create and preserve an institutional framework appropriate to such practices. ... State interventions in markets (once created) must be kept to a bare minimum because, according to the theory, the state cannot possibly possess enough information to second-guess market signals (prices) and because powerful interest groups will inevitably distort and bias state interventions (particularly in democracies) for their own benefit.
} 
nature and legitimacy of state power. Section III considers two objections to the recognition of material inequality as a constitutional problem, and responds to them. Section IV seeks to outline two classes of constitutional solutions that could be offered to the problem: egalitarian solutions and anti-plutocratic solutions. As this article is an internal critique of liberal constitutionalism, the proposed solutions are discussed with an eye to their efficacy and their compatibility with liberal constitutional theory and practice. Finally, Section V summarises the arguments of this article and identifies certain agendas for further research. Before proceeding, a caveat: inequality within states is a function not only of the domestic policies of the state, but also of the normative and regulatory structure of the international order. The arguments of this article are premised on the belief that constitutional law can do something - if not everything - in addressing the problem of inequality within states; and also that a recognition of material inequality as a constitutional problem by a critical mass of influential states has the potential to reform the international order as well.

\section{Convertibility, subtlety and resilience of power: Rise of liberal plutocracies}

Power is convertible, subtle, and resilient. When the gap between groups at the top and those at the bottom of any material scale becomes wide enough to translate into the power of one over the another, all these three features of power kick in.

First, power, understood in the relational sense of a person having power over another, is convertible. Scholarly discourses often distribute human activity into different domains, such as the social, the economic, and the political. In reality, however, the same individuals inhabit all these domains, and move freely between them. These 'domains' are not watertight: rather, they interact, influence, and seep into each other. It may be possible to organise a society where these domains are more tightly sealed: the guardians in Plato's ideal Republic, for example, would wield enormous political power but would be permitted barely enough material resources to ensure their survival. ${ }^{24}$ Walzer's model of 'complex equality' seeks to establish a similar system of autonomous spheres, such that:

$[\mathrm{N}]$ o citizen's standing in one sphere or with regard to one social good can be undercut by his standing in some other sphere, with regard to some other good. Thus, citizen $\mathrm{X}$ may be chosen over citizen $\mathrm{Y}$ for political office, and then the two of them will be unequal in the sphere

24 Plato, Republic (Robin Waterfield trans, Oxford University Press, Oxford, 1993) 121. 
of politics. But they will not be unequal generally so long as X's office gives him no advantages over $\mathrm{Y}$ in any other sphere-superior medical care, access to better schools for his children, entrepreneurial opportunities, and so on. ${ }^{25}$

Walzer codified his maxim of complex equality thus: 'No social good $\mathrm{x}$ should be distributed to men and women who possess some other good y merely because they possess $y$ and without regard to the meaning of x. ${ }^{26}$ Most liberal democracies fail to satisfy this maxim. In our societies, power in one domain has the ability to, and will typically have the will to, convert itself into power in other domains as well. In this world with permeable domains, even if one was interested simply in being materially powerful, but had no interest in political or social power, the fact that political and social power can influence (even reduce) one's economic power would often be sufficient incentive to secure power (or, at least, influence) in these other domains as well. ${ }^{27}$ Indeed, the liberal legitimacy constraint demanding fair political opportunity for all citizens may be seen as a Platonic aspiration for a measure of autonomy between the domains of politics and economics - a desire to ensure that material power does not determine political power.

It is this feature of power - its convertibility - which ensures that formal political equality (through one-person-one-vote, universal franchise, equal political office eligibility rules, and free and fair elections) does not necessarily translate into fair political opportunity for all. There are means of influencing politics other than the vote, and these other means are not distributed equally. Rather, they depend very much on economic and socio-cultural power. Liberal constitutionalism accepts this much more readily when it comes to the metamorphosis of social power into political power. Minorities, defined by a socially salient characteristic such as religion or race, who fear being locked out of political power have frequently been offered political insurance by liberal constitutions in the form of consociationalism, centripetalism, rights guarantees, legislative quotas, and federalism. ${ }^{28}$ Our relative ease in accepting the convertibility of social power into political power, at least in part, might be owed to the fact that the mechanism of such conversion usually passes through one-person-one-vote:

${ }^{25} \mathrm{M}$ Walzer, Spheres of Justice: A Defence of Pluralism and Equality (Martin Robertson, Oxford, 1983) 19.

26 Ibid 20.

${ }^{27}$ For some of the techniques used by the rich to maintain political influence in the United States, see RP Formisano, 'Political Inequality' in Plutocracy in America (Johns Hopkins University Press, Baltimore, MD, 2015).

28 See generally J McGarry, B O’Leary and R Simeon, 'Integration or Accommodation? The Enduring Debate in Conflict Regulation' in Constitutional Design for Divided Societies (n 14) 42. 
we assume that when social identities are salient, voting preferences of social majorities as well as minorities are likely to be shaped by these identities. The conversion is therefore clear and direct. But this is not always the case, even with respect to social power. Consider political insurance for socially vulnerable groups that are not necessarily numerical minorities typically women, but also 'lower' caste groups in India. Representational preferences and constitutional rights for women and caste groups seek to make social power less mutable precisely because of the limited ability of formal political equality to achieve that result, despite their numerical strength in the voting population. The poor are similarly unable to translate their numerical advantage into political power despite formal political equality. Walzer's system of complex equality, if ever achieved, is likely to be unstable because it fails to take sufficient account of two other features of power that make convertibility irresistible: its subtlety and its resilience. ${ }^{29}$

The second characteristic of power is that it can be subtle. Lukes identified three dimensions of power. In the first dimension, power is the capacity of A to get B to do something B would not otherwise do. ${ }^{30}$ In its second dimension, power is the capacity to skew political values and institutional practices so that matters that threaten power are taken off the political agenda. ${ }^{31}$ These dimensions relate to communal decision-making (or non-decision-making), entail observable (overt or covert) conflict between the powerful and the less powerful, and concern the will (or subjective preferences) of the actors involved. ${ }^{32}$ Lukes identifies a third subtle - form of power, one which goes beyond decision-making, may entail latent rather than observable conflict, and concerns the actual interests of the participants rather than their will or preference. In this third dimension, power is so secure that the powerful are unaware of any potential challengers to the existing structural bias that benefits them, and which they work to maintain - not through conscious decisions but by socially structured and culturally patterned behaviour. ${ }^{33}$ This form of power can be so 'effective and insidious' that it forestalls challenge arising to it, usually by influencing and shaping the preferences of those upon whom it operates. ${ }^{34}$ The dominated may not even know their interests are

29 For an account of the mechanisms through which economic power converts itself into political power, see TK Kuhner, 'American Plutocracy' (2015) 26(1) King's Law Journal 44.

30 S Lukes, Power: A Radical View (2nd edn, Palgrave MacMillan, New York, NY, 2005) 16.

31 Ibid 20.

32 Ibid 29.

33 Ibid 25-6.

34 Ibid 27. This understanding of subtle power has obvious resonance with Gramsci's notion of 'hegemony'. See also J Nye, 'Soft Power' (Autumn 1990) 80 Foreign Policy 153, 166 , who describes 'co-optive or soft power' as X's ability to get $\mathrm{Y}$ to 'want what it wants'. 
being harmed. ${ }^{35}$ While the potential for conflict always exists where there is power, there may not be any observable conflict. Power can also misdiagnose and mis-explain its impact - for example, it can blame democratic institutions rather than neoliberal ones for gross inequality. This does not necessarily avoid conflict, but targets anger towards another adversary. In this third form, power operates, but need not be exercised. Its very existence - as a capacity that certain persons have in relation to others - is problematic. ${ }^{36}$

Finally, power is resilient. Power constantly seeks to perpetuate and strengthen itself, and has the ability to do so. Not only does it present a moving target to anyone seeking to tame it, it is also extremely adaptable in the face of such efforts. Burke worried that mere universal franchise would lead to too much equality. ${ }^{37}$ Formal political equality should have ameliorated some of the worst excesses of the naked exercise of power, but has turned out to be fully compatible with extreme forms of inequality. ${ }^{38}$ This is, in no small part, due to power's resilience. Its convertibility and subtlety no doubt aid this resilience. But there are other tools too - power can silence its critics and challengers. It can buy them out. It can threaten or eliminate them. It can also co-opt them - this last tool ensures that even as individuals are sometimes able to move between classes, different economic classes themselves have a relatively stable existence. Its resilience makes it the ultimate self-enforcing phenomenon - power begets power. Given this, preventive measures that stop a power relation from developing in the first place are likely to be more effective than measures that seek merely to constrain its operation.

Just as liberal states that follow neoliberal policies are likely to become more unequal over time, unequal liberal states that equate fair political opportunity with formal political equality are likely to see a political lockout of the poor. While democracies do not guarantee that all groups will enjoy access to power all the time, they must ensure that no group is locked out of accessing an adequate level of power, enough number of

35 Lukes (n 30) 28.

36 Ferejohn makes the same point by suggesting that the powerful can frustrate redistribution either by changing the preferences of the median voter, or by ensuring that political officials do not respond to the redistributive preferences of the median voter: J Ferejohn, 'Is Inequality a Threat to Democracy?' in L Jacobs and D King (eds), The Unsustainable American State (Oxford University Press, Oxford, 2009) 34, 46.

37 E Burke, Reflections on the Revolution in France (2nd edn, J Dodsley, London, 1790).

38 A Bonica, N McCarty, KT Poole and H Rosenthal, 'Why Hasn't Democracy Slowed Rising Inequality?' (2013) 27(3) Journal of Economic Perspectives 103, 103; J Mayer, Dark Money: The Hidden History of the Billionaires Behind the Rise of the Radical Right (Anchor Books, New York, NY, 2017). 
times, for the system to remain 'democratic'. ${ }^{39}$ In extremely unequal societies, the very poor are locked out of power because of the conversion of material power into political power. As inequality increases, the materially rich will seek to maintain and deepen their economic power. Doing so will require greater influence on politics by the rich and reduced influence by the poor. Thus, the rich are likely to seek to secure their political power by disenfranchising the poor - making it harder for them to vote by imposing demanding procedural requirements (such as identity verification), increasing barriers to running for office by making or keeping electioneering expensive and opposing campaign finance reforms, using political funding and lobbying to secure the election of favourable politicians and the adoption of favourable policies, converting material power into media power to support particular ideologies, and so on. This last feature underlines power's subtlety, giving it the capacity to sometimes even convince the poor to vote against their own interests. All this is plausible and has precedent. Liberal democracies which adopt neoliberal policies, it seems, are forever in danger of becoming plutocracies. Power's subtlety can secure the ideological legitimacy of this lockout, through its control or influence over opinion-makers, especially in media, politics and the academy. The astonishingly widespread acceptability of neoliberalism, despite its impact on disenfranchisement of the poor, is a case in point. Finally, once a plutocracy is in place, power's resilience makes it very difficult to unseat it. Basically, the movement from plutocracy to democracy is extremely difficult. This enduring lockout of the relative poor from political power seriously undermines the legitimacy of a liberal constitution.

Is there evidence to support the claim that under neoliberalism, inequality is exacerbated, and that the resulting imbalance in material power between the rich and the poor leads to a political lockout of the very poor? The first part of the claim - that neoliberal policies result in gross inequality - is relatively uncontroversial, and accepted even by many neoliberals. The 2016 Human Development Report notes 'Rising incomes around the world have been accompanied by widening inequality.' ${ }^{40}$ Economic data since the 1980s has unambiguously belied Kuznet's hypothesis that high income and development levels would result in a reduction in inequality. ${ }^{41}$

39 This is not the place to define what these adequacy thresholds might be. My assumption is that, wherever we might set them, the relative poor - as a group - fail to meet them in very unequal societies.

40 United Nations Development Programme, 'Human Development Report 2016: Human Development for Everyone’ (2016) <http://hdr.undp.org/sites/default/files/2016_human_ development_report.pdf $>30$.

41 B Milanović, Global Inequality: A New Approach for the Age of Globalization (Harvard University Press, Cambridge, MA, 2016) 46-7. 
In 2017, Oxfam reported that the richest eight people in the world had as much wealth as the poorest 50 per cent of the world's population, i.e. 3.6 billion people! ${ }^{42}$ Neoliberals nonetheless insist that inequality is a price worth paying for the reduction in absolute poverty that comes about through these policies. Recent empirical research is challenging even this latter claim, showing that it is based on (i) a very low threshold for calculating absolute poverty, (ii) a reduction of the proportion of people living in absolute poverty as populations rise, but the figures of total number of people living in poverty hasn't declined by much, and (iii) decline that has largely come from a single country: China. ${ }^{43}$ Whatever the impact of neoliberalism on absolute poverty, there is no denying its catastrophic consequences for relative poverty.

The second part of the claim - that gross material inequality leads to the political lockout of the poor - is harder to establish empirically. There are three main ways of measuring the political power of a group: do its members vote, do its members get elected to political office, and do elected politicians adopt policies favouring the group? All these three factors are easier to measure for discrete social groups like women or Dalits (former 'untouchable' castes in India). Things are harder with regard to the poor, at least with respect to the two latter criteria. Upon election, the perks of public office often break the connection between the public official and her economic class - she, personally, is less likely to be 'poor' any more, even assuming the absence of corruption (since most liberal states, unlike Plato's ideal Republic, pay reasonable salaries to their elected officials). Whether a policy is pro-poor is often difficult to determine with certainty (more on this 'transparency' concern below). Little surprise then that most existing studies are concerned with inequality's relationship with political participation in a narrow sense (usually through voting in official elections, although some studies do focus on informal mechanisms of participation as well). ${ }^{44}$ While the evidence on the ability of the poor to participate in politics is mixed, many of these studies assume (without proof) that political participation in itself translates into political power. ${ }^{45}$ Even if the poor

42 J Hickel, The Divide (W. W. Norton \& Co, New York, NY, 2017) 16.

43 Ibid $15,37 \mathrm{ff}$.

44 There are concerns that current measures for assessing the quality of a democracy are inadequate, because they understand 'freedom' as non-interference rather than capability, and that the latter is more sensitive to the impact of material inequality on political participation. See generally J Brown, 'Freedom as Capability: How the Capability Approach Can Improve Our Understanding of Freedom in Established Democracies' (PhD thesis, University of Melbourne, 2017).

45 LM Bartels, 'Economic Inequality and Political Representation' in L Jacobs and D King (eds), The Unsustainable American State (Oxford University Press, Oxford, 2009) 167, 168; see also JE Stiglitz, The Price of Inequality (W. W. Norton \& Co, New York, NY, 2012) 8-9. 
can and do participate formally in elections, do they wield sufficient political power to have their interests sufficiently catered to by state policy?

At least one influential study shows that they don't. ${ }^{46}$ One study is not conclusive proof, but we can speculate with some confidence. In normal circumstances, we should expect the poor to use any political power they might have to stem the tide of rising inequality. ${ }^{47}$ The assumption is based on the convertibility of power - if the poor have political power but (by definition) lack material power, we should expect them to try to convert their political power to material power. This is likely especially given the strong psychological aversion humans have for social inequality (when they are on the relatively deprived side of the relation). ${ }^{48}$ In societies we are concerned with, no such stemming appears to have happened in the last three decades. Unless we see data to the contrary that demonstrates that somehow the very poor have political power that they are choosing not to exercise (for reasons other than the operation of material, sociocultural, political, or discursive power of the rich over them) to stem rising inequality and thereby garner some material power, we can safely surmise that many liberal regimes today that follow neoliberal economic policies are functional plutocracies. It is possible that the level of economic inequality that triggers a political lockout is different in different societies. Clearly, more empirical research is called for. Even so, the conceptual claims made herein are plausible, and not disputed by available evidence.

Another empirical dataset is relevant here. This literature explores the connection between inequality and the rise of authoritarianism in democracies. ${ }^{49}$ The controversial claim being made here is that democracies that undergo a reversal or backsliding tend to have higher levels of inequality. ${ }^{50}$ In very unequal societies, support for authoritarianism seems to come not just from the relative poor but also from the relative rich. ${ }^{51}$ The connection between inequality and authoritarianism is not of direct

46 M Gilens and BI Page, 'Testing Theories of American Politics: Elites, Interest Groups and Average Citizens' (2014) 12(3) Perspectives on Politics 564.

47 Stiglitz (n 45) Ch 5.

48 R Wilkinson and K Pickett, The Inner Level: How More Equal Societies Reduce Stress, Restore Sanity and Improve Everyone's Well-being (Penguin, London, 2018).

49 A Przeworski, 'The Poor and the Viability of Democracy' in A Krishna (ed), Poverty, Participation, and Democracy: A Global Perspective (Cambridge University Press, Cambridge, 2008) 125.

50 EB Kapstein and N Converse, 'Why Democracies Fail' (2008) 19(4) Journal of Democracy 57; see also C Tilly, 'Inequality, Democratization, and De-Democratization' (2003) 21(1) Sociological Theory 37.

51 F Mols and J Jetten, The Wealth Paradox: Economic Prosperity and the Hardening of Attitudes (Cambridge University Press, Cambridge, 2017). 
relevance to this article, as our main concern is with plutocracy. Even so, if the alleged connection between inequality and authoritarianism does exist, it may be explained as a manifestation of the stability worry in a system where a key group is locked out of power. In other words, we should expect the poor to want to change a system in which they are locked out of power - the fact that the chosen alternative often exacerbates, rather than ameliorates, their relative poverty is a testament to the subtlety and resilience of power. So is the case even if the poor do not in fact think there is any problem with their political lockout (or, do not believe they are indeed locked out) - the legitimacy problem is an objective concern that exists because of the fact of the poor are locked out of power, whether or not they (or others) believe that to be the case.

It seems, then, that liberal democracies are forever at risk of becoming plutocracies, which in turn may become vulnerable to populist revolts and authoritarianism. Without a serious commitment to keeping material inequality within reasonable bounds and insulating politics from the economy, they breach the legitimacy constraint of securing fair political opportunity to all citizens. The rate at which a state should tax shoes, usually, is an ordinary policy question rather than a constitutional question. It does not typically concern the very basis on which the legitimacy of a particular constitutional form depends. The ability of a state to hold free and fair elections, on the other hand, is a constitutional issue if its legitimacy rests on a democratic basis. This is why the problem of gross material inequality is a constitutional problem - it fundamentally alters the very nature and legitimacy of state power.

\section{A constitutional theory problem: Two objections}

The problem identified in the two preceding sections lies embedded in the fundamental structures of liberal constitutionalism. A failure to satisfy the legitimacy constraint imposed by liberal constitutionalism is best fixed in the constitution itself. Constitutionalisation seeks to elevate an issue above the vagaries of partisan politics by entrenching it. A constitutional policy is the policy of the state, rather than merely the policy of a particular government. Recent research shows that constitutions are increasingly detailed in their substantive policy prescriptions, and the older notion of purely procedural constitutions is very much a thing of the past. ${ }^{52}$

\footnotetext{
52 M Versteeg and E Zackin, 'Constitutions Unentrenched: Toward an Alternative Theory of Constitutional Design' (2016) 110(4) American Political Science Review 657; JZ Benvindo, On the Limits of Constitutional Adjudication (Springer Verlag, Berlin 2010).
} 
A constitutional concern with gross inequality and political lockout of the poor should not therefore be rejected simply on the basis that it embeds a substantive policy goal in a constitution. That said, there are two objections that need to be considered before we can move to considering substantive solutions.

\section{Transparency and counter-majoritarian concerns}

The first objection is a familiar one in constitutional theory. It entails a worry about the transparency of constitutional norms. If serious breaches of constitutional norms are not straightforwardly obvious to citizens and officials, defending and sustaining a constitution becomes difficult. This was Rawls's chief rationale for insisting that the difference principle (that requires distributive justice) should not be a constitutional essential. ${ }^{53}$ A corollary of the transparency concern is an institutional worry that in the absence of such transparency, judges alone assume the power to call out any breaches. This has led to familiar debates around the counter-majoritarian difficulty. In effect, the objection is this: either the constitutional norm is so opaque that nobody knows if it has been breached (thereby making the constitution irrelevant), or the judiciary takes over the task of authoritatively determining whether there has been a breach (thereby undermining democracy).

Two responses may be made to this objection. First, whatever the force of the objection, it is no more applicable to a constitutional concern with material inequality than to other things we accept as constitutional essentials - the right against discrimination, the right to privacy and the division of powers between federal and state governments. Rawls went further than many liberal constitutionalists to include the guarantee of basic needs and of fair political opportunity in his list of constitutional essentials. ${ }^{54}$ There are many non-transparent things that constitutional theory and constitutional practice accept as legitimate objects of constitutionalisation. Transparency is no doubt an important virtue that constitutional provisions ought to possess, to the extent possible. But it hasn't been treated as a sine qua non in constitutional discourse and practice, not even by Rawls himself.

What the transparency objection does tell us, however, is that whatever solution is adopted must have some bite. We will not solve the problem at hand by adopting a normative solution pitched at such a high level of

53 Rawls (n 1) 47-8; see also Rawls (n 16) 228-9. On why this claim is hard to defend conceptually, see F Michelman, 'Poverty in Liberalism: A Comment on the Constitutional Essentials' (2012) 60(4) Drake Law Review 1001; C Fabre, Social Rights under the Constitution: Government and the Decent Life (Oxford University Press, Oxford, 2004) 83-6.

54 Rawls (n 1) 149. 
generality that its breach is rarely apparent. Provisions requiring the state to pursue broad and vague goals such as 'social justice' or 'the common good', as are often found in some constitutional preambles and directives, are too non-transparent to be helpful on their own. Some degree of transparency is necessary for the effectiveness of any constitutional provision, and for maintaining the legitimacy of any interpreting institution that specifies its meaning in particular circumstances.

Secondly, there is a significant volume of literature that deals with designing non-transparent provisions in a manner that ameliorates the counter-majoritarian worry. Weak-form judicial review, in particular, has been explored as a viable possibility in polycentric cases. In preserving a continuing role for the legislature, at least some of the counter-majoritarian worries are assuaged. Putative solutions will need to be similarly sensitive to these institutional concerns.

\section{The limited potency of politics and law}

A second objection might be based on the claim that the economy is an autonomous domain, where any political or legal intervention is likely to lead to unintended consequences. A stronger version of the objection is that law and politics are more or less impotent in achieving their specified goals with regard to the economy - although they can affect the economy, they are unable to do so in the way they might wish to. This objection essentially assumes that the market is stronger than the state - while material distribution can and does have an impact on politics, the options for law and politics to impact this distribution in a foreseeable manner are limited.

At least the stronger version of the objection can be rejected outright. Piketty shows that politics matters to the distribution of income and wealth in societies, and that material inequality is not some natural phenomenon that will inevitably occur. ${ }^{55}$ His analysis shows that economic determinism is false, and that political choices have made and can make significant difference to the nature and extent of material inequality in a society. ${ }^{56}$

So, while policies may have unintended consequences, politicians broadly seem to know what they need to do to make a country less unequal. This data is also important to note when considering external scepticism about the ability of liberal states to deal with inequality.

55 See also JE Stiglitz, The Great Divide: Unequal Societies and What We Can Do about Them (W. W. Norton \& Co, New York, NY, 2016) 105ff.

56 T Piketty, Capital in the Twenty-First Century (A Goldhammer trans, Harvard University Press, Cambridge, MA, 2014) 20. 
While it may be that liberal constitutional systems 'have a tendency to function as oligarchies ... resulting from elites' predatory instincts and self-serving behaviour', ${ }^{57}$ the data belies the claim that autocratic strong states alone can mobilise the resources needed for equitable development. ${ }^{58}$ After all, convertibility of power permits not only the translation of economic power to political power, but also the other way round.

The objection is better understood not in terms of a comprehensive impotence of politics in shaping the economy, but rather in terms of a limited degree of autonomy that the economy might enjoy from politics. The economy is a complex system, and political choices do sometimes backfire, and some may well have unintended consequences. Often, a wide range of possible policy solutions are available, each of which might incur a different set of costs and benefits, and some of which might be more suitable in certain contexts than others. Constitutions need to leave enough space for politicians to be able to experiment, to try out different solutions, and to see what works and what doesn't. In other words, there doesn't seem to be a single magic bullet policy solution that could solve the problem of gross inequality for all societies at all times. Since constitutions are aspirationally longlasting, it will be unwise to constitutionalise a policy solution at too high a degree of specificity. That said, it is a mistake to equate constitutional flexibility with respect to the economy with political neutrality - while the former is possible, and perhaps desirable, the latter is an impossibility. A laissez-faire economic policy is as much a political choice with as significant (and sometimes unpredictable) consequences as more interventionist policy - all forms of relationships between the state and the market are normative and ideological. Since inaction is as much a choice as action, refusing to choose the nature of this relationship is not a luxury available to any state.

A subset of this objection particularly targets any judicial role in redistributive decision. Whatever competence politicians may have in managing the economy, the argument goes, judges are even less qualified. In Fuller's classic account, judges are ill-suited for making 'polycentric' decisions, decisions which are embedded in a complex web of interrelated activities, so that any intervention in one activity is likely to have significant, but unpredictable, consequences for many others. ${ }^{59}$ Again, this argument

57 AP Tsygankov, The Strong State in Russia: Development and Crisis (Oxford University Press, Oxford, 2014) 7.

${ }^{58}$ Ibid 9. This is not to suggest that the argument between liberal and autocratic constitutionalism turns solely on their respective abilities to deal with inequalities. As a value pluralist, I believe that states should care about many things - preventing extreme inequality is just one of them.

59 LL Fuller and K Winston, 'The Forms and Limits of Adjudication' (1978) 92(2) Harvard Law Review 353. 
bites only if we equate constitutionalisation with a legal right to material equality that would invite full-fledged and substantive judicial intervention. Constitutionalism has developed many sophisticated tools to deal with the problem of polycentricity in other domains, including empowering judges to nudge political decision-making rather than make substantive decisions themselves, and imposing non-judiciable obligations directly on politicians. ${ }^{60}$

We can see that the two objections, while not fatal to the need to deal with gross material inequality constitutionally, pull in opposite directions. The transparency and counter-majoritarian concerns pull towards clear and definite constitutional responses, whereas the relative autonomy of economics from law and politics demands flexible solutions that eschew specification. These opposite pulls make efforts to find a feasible solution particularly difficult, although no more so than other competing values that need to be balanced in most complex decisions. They are best treated as design instructions that should be taken into consideration when designing constitutional responses to gross material inequality in a given socio-economic and political context.

\section{Two types of constitutional responses: Egalitarian and anti-plutocratic solutions}

Gross material inequality, I have argued, is problematic for liberal constitutionalism for instrumental reasons - it belies the liberal promise of political equality, thereby making the regime illegitimate by the yardstick of liberalism's own moral commitments. There is no suggestion that these are the only reasons why gross material inequality is problematic - there may well be many other intrinsic or instrumental reasons why that may be so. But at least for our purposes, two types of constitutional responses are possible to address the problem with respect to liberal constitutionalism. First, constitutional solutions could tackle gross inequality itself, to make sure that inequality is not allowed to cross the threshold where it becomes problematic for liberal constitutionalism. I will call this set egalitarian solutions. Second, constitutional responses could focus on preventing the worrisome consequence of gross material inequality - political exclusion of the less well-off - from being realised. These are the anti-plutocratic solutions. The first strategy would constitutionalise the objective of keeping material inequality under control, whereas the second will ensure access to

60 See T Khaitan, 'Constitutional Directives: Morally Committed Political Constitutionalism' (2019) 82(4) Modern Law Review 603. 
political power to the relative poor. ${ }^{61}$ The first constitutionalises a measure of material egalitarianism, the second embodies the anti-plutocratic norm. The two are, of course, interrelated, and mutually complementary. Equality will ensure a plutocracy does not emerge, whereas genuine and continuous access to political and discursive power to the relative poor is probably the best mechanism to keep levels of inequality under check.

Before we consider these responses, four caveats are in order. First, I will not consider solutions that compromise the overall liberal character of the state. Solutions to gross material inequality outside the liberal constitutional framework are no doubt possible. But the purpose of this article is to consider whether the liberal democratic tradition has internal resources to address the problem. Most of the proposed solutions are already practised in some liberal states, or are incremental developments of these practices. Second, simply because these are constitutional solutions should not lead to the assumption that they are relevant only to countries that are writing a new constitution (although there are quite a few of those too). Constitutions change all the time, and not just by a formal amendment. Political and judicial actors are able to tweak, nudge, sometimes radically alter, constitutions even in systems where a formal change is very difficult to achieve. ${ }^{62}$ While the local context matters significantly when it comes to feasibility of any change, constitutional actors in all liberal constitutions could benefit from thinking about the possibilities outlined below. Third, given the worries about transparency and the potency of politics canvassed in the previous section, these solutions are sensitive to liberal values such as separation of powers and rule of law, while also worrying about the need to ensure the effectiveness of any institutional mechanisms. Finally, what norms and institutional design will be effective is likely to depend on the context. The ideas presented in this section are offered more as food for thought than as a manifesto.

\section{Egalitarian solutions to contain material inequality}

The best way to ensure that a democracy does not become a plutocracy is by ensuring that there are no plutocrats. An effective constitutional commitment to a measure of material egalitarianism could achieve that goal. A commitment to full equality of resources would probably require measures that are incompatible with liberalism. But the goal to prevent material inequality from becoming excessive is different - as I have argued in this article, not only is this goal compatible with liberalism, it is

61 Some of these strategies may map only policy and power based forms of political insurance classified by Dixon and Ginsburg. See generally, Dixon and Ginsburg (n 7) 999.

62 See generally, O Doyle, 'Informal Constitutional Change' (2017) 65(5) Buffalo Law Review 739. 
a corollary of a commitment to liberal constitutionalism. ${ }^{63}$ An egalitarian constitutional norm is likely to take one of four forms. These are not mutually exclusive, and constitutions often feature more than one of them simultaneously.

Material equality as a preambular value. First, an egalitarian norm may be expressed in the preamble or a statement of fundamental values of a constitution. At this most abstract level, a constitutional commitment to keep material inequality under check can take multiple forms. A constitutional preamble can commit the state to 'equality' per se, ${ }^{64}$ or 'equal protection by law' ${ }^{\prime 65}$ or some other variation thereof. Although ubiquitous in the preambles of newer constitutions, ${ }^{66}$ some older preambles, such as those in the Constitutions of Australia and the United States, make no mention of equality as a foundational value. Even preambles that do mention equality tend not to imply resource or material equality. Perhaps the Indian formula demanding 'equality of status and of opportunity' goes furthest. ${ }^{67}$ Some verbal imagination will be needed to embody the qualified value of material equality in a pithy phrase apt for preambular commitment.

A preambular egalitarian norm can perform an identitarian and expressive function for the polity. ${ }^{68}$ Preambular commitments can also perform a legitimating function for political and judicial actions geared towards their objectives. As normative commitments go, they are helpful in structuring an egalitarian normative environment. Beyond that, their effectiveness depends on particular constitutional contexts - some countries take their constitutions' preambles a lot more seriously than others. ${ }^{69}$

Such a preambular commitment to a measure of material equality could also encourage the judiciary to adopt a more restrictive approach

63 Determining when inequality has become excessive empirically is an important issue, but beyond the scope of this article. Conceptually, it is excessive when the poor are in danger of political lockout or have been locked out of political power.

64 Brazilian Constitution, preamble; Andorra Constitution, art 1, para 2.

65 South African Constitution, preamble.

66 This should be unsurprising, given how similar preambles are to one another: T Ginsburg, N Foti and D Rockmore, "We the Peoples": The Global Origins of Constitutional Preambles' (2014) 46(2) George Washington International Law Review 101.

${ }^{67}$ Indian Constitution, preamble.

68 S Levinson, 'Do Constitutions Have a Point? Reflections on "Parchment Barriers" and Preambles' (2011) 28(1) Social Philosophy and Policy 150; DS Law, 'Constitutional Archetypes' (2016) 95(2) Texas Law Review 153; G Jacobsohn, Constitutional Identity (Harvard University Press, Cambridge, MA, 2010).

${ }^{69}$ L Orgad, 'The Preamble in Constitutional Interpretation' (2010) 8(4) International Journal of Constitutional Law 714; JO Frosini, 'Constitutional Preambles: More than Just a Narration of History' (2017) 2 University of Illinois Law Review 603. 
to the right to property, which tends to be the chief legal hurdle to any robust redistributive programme. ${ }^{70}$ Given the near-universal acceptance of progressive taxation in most liberal states, and that of inheritance tax in many of them, it cannot be the case that the liberal right to property comprehensively forbids redistribution. ${ }^{71}$ Respect for property is indeed a key liberal value, but it is only one among many others (including fair political opportunity), and does not take precedence over these other values. $^{72}$

The only issue about the compatibility of a redistributive programme with the right to property is the proportionality of the former's impact on the latter. This is, no doubt, a contextual inquiry that requires a case-bycase consideration. Even so, the arguments of this article lend considerable weight to the interests served by a redistributive programme under any balancing exercise in a proportionality analysis - few things are weightier than the health of a democratic system itself. Once this is accounted for, significant restrictions on the right to property of the very rich should be permissible.

In particular, liberal constitutions have the necessary resources to draw a distinction between private property rights of natural persons and those of large corporations, just as these distinctions are sometimes drawn in the context of the right to free speech or free exercise of religion. ${ }^{73}$ It is well recognised in the liberal tradition that while nonnatural persons may sometimes have fundamental rights, these rights may have a limited scope, and be more readily limitable, than those of natural persons. In the particular context of property, Sempill draws a distinction between the right to property as a right over 'mere things' and the exercise of the substantial investment power (including the power to withdraw investments) that large corporations exercise not

70 R Walsh, 'The Constitution, Property Rights and Proportionality: A Reappraisal' (2009) 31 Dublin University Law Journal 1; N Wahi, 'Property' in S Choudhry, M Khosla and PB Mehta (eds), The Oxford Handbook of the Indian Constitution (Oxford University Press, Oxford, 2016) 943.

${ }^{71}$ Even in the United States, scholarly arguments concerning the constitutionality of progressive taxation are dated: WJ Blum and H Kalven, 'The Uneasy Case of Progressive Taxation' (1952) 19(3) University of Chicago Law Review 417; RC Brown, 'Constitutional Limitations on Progressive Taxation of Gross Income' (1937) 22 Iowa Law Review 246; SD Pollack, 'Origins of the Modern Income Tax, 1894-1913' (2013) 66(1) Tax Lawyer 295.

72 Rawls (n 1) 149.

73 E Pollman, 'Citizens Not United: The Lack of Stockholder Voluntariness in Corporate Political Speech' (2009) 119 Yale Law Journal Online 53 <https://www.yalelawjournal.org/ pdf/823_pa5w1bp2.pdf>; Burwell v Hobby Lobby Stores, Inc., 573 U.S. 682 (2014), Amicus Curiae Brief filed by Corporate and Criminal Law Professors in Support of Petitioners; KM Sullivan, 'Two Concepts of Freedom of Speech' (2010) 124 Harvard Law Review 143. 
just over things, but persons, even communities. ${ }^{74}$ Preambular commitments to equality can draw judicial attention to the importance of articulated values and invite a more nuanced approach to the right to property.

A limited right to material equality. Secondly, constitutions can guarantee some form of equality as a judicially enforceable right. Most liberal constitutions do guarantee a 'right to equality' or some variation thereof ('equal protection of the laws', 'equality before law' etc). In most jurisdictions, however, this right is understood not as a guarantee of any measure of material inequality. It is, instead, interpreted as a source for demanding rationality, non-arbitrariness, or antidiscrimination (based on personal characteristics such as race, sex etc, but typically not class) in state action. ${ }^{75}$

This cautious judicial approach to the right to equality stems from concerns relating to polycentricity and flexibility, which make the judiciary less than ideal for guaranteeing material equality. The least radical departure from existing practice - doctrinally - would be to expand the list of protected groups to include the relative poor. ${ }^{76}$ At least in constitutions that allow the judiciary to expand this list to include groups analogous to those already protected, ${ }^{77}$ those at the bottom of the material distribution scale are as deserving of the protection of antidiscrimination law as racial and religious minorities, women, LGBTQ people, and disabled persons. ${ }^{78}$ A doctrinal development along these lines could also serve as a useful interpretive aid to nudge courts to construe ambiguous laws in favour of the poor.

Another possible route to incorporating a material dimension to the right to equality, without the embrace of a full-fledged judicial redistributive programme, could be through reading in a procedural duty on political actors to give due regard to reducing material inequality during policymaking. A comparable 'positive duty' is statutorily enshrined in section 1 of the UK Equality Act 2010, although it has been brought into force only in Scotland.

74 JA Sempill, 'What Rendered Ancient Tyrants Detestable: The Rule of Law and the Constitution of Corporate Power' (2018) 10(2) Hague Journal on the Rule of Law 219, 228-9.

75 T Khaitan, 'Discrimination' in R Grote, F Lachenmann and R Wolfrum (eds), Max Planck Encyclopedia of Comparative Constitutional Law (Oxford University Press, Oxford, 2017); T Khaitan, 'Equality: Legislative Review under Article 14' in Oxford Handbook of the Indian Constitution (n 70) 699.

76 Some international and regional law instruments, and a few national constitutions, already protect 'socioeconomic status' as a ground of non-discrimination. See Dixon and Suk (n 13) 382-3.

77 For example, section 15 of the Canadian Charter of Rights and Freedoms.

78 See generally Committee on Economic, Social and Cultural Rights, General Comment No 20, 2 July 2009, UN Doc E/C.12/GC/20/. 
Such a duty will avoid substantive judgment by courts, and therefore less liable to invite concerns about judicial capacity. ${ }^{79}$ In fact, judges are very familiar with this type of procedural scrutiny in administrative law, and the suggested expansion - as a facet of the ubiquitous right to equality can focus the attention of the political branches to the problem of material inequality.

What the judiciary can also do very well is guarantee some other rights which make a society more equal, even if these other rights are not motivated primarily by any egalitarian principle. A robust judicial protection of social rights, including the rights to shelter, education, nutrition, and other essentials, go some way in helping those at the bottom of the economic ladder. ${ }^{80}$ The theory and practice concerning judicial capacity with regard to the implementation of social rights is fairly sophisticated, and does not need revisiting here. ${ }^{81}$ Suffice it to say that a cautious and contained judicial enforcement of social rights is certainly viable, and justifiable. ${ }^{82}$ It will help the cause of material equality further if the usual list of social rights could come to include at least two further ingredients (at least in societies that are able to afford it): a guaranteed universal basic income and a right to tertiary education.

The first of these two proposed social rights would guarantee a generous basic income to all citizens/members of a polity without any qualifications. ${ }^{83}$ Such a constitutional right to a citizen's income is likely to serve the egalitarian purpose only if it is in addition to, rather than a replacement for, other pre-existing social rights to housing, education, employment etc; and if the right is funded by a tax burden that largely falls on the rich (through, say, a much higher income tax for the rich and/or a tax on wealth or capital). ${ }^{84}$

79 A McColgan, 'Litigating the Public Sector Equality Duty: The Story So Far' (2015) 35(3) Oxford Journal of Legal Studies 453.

80 FI Michelman, 'The Supreme Court: 1968 Term' (1969) 83(1) Harvard Law Review 7.

81 See generally D Bilchitz, Poverty and Fundamental Rights: The Justification and Enforcement of Socio-Economic Rights (Oxford University Press, Oxford, 2008); S Fredman, Human Rights Transformed: Positive Rights and Positive Duties (Oxford University Press, Oxford, 2008).

82 J King, Judging Social Rights (Cambridge University Press, Cambridge, 2012); Cf. M Tushnet, 'Social Welfare Rights and the Forms of Judicial Review' (2003) 82(7) Texas Law Review 1895.

${ }^{83} \mathrm{P}$ van Parijs and Y Vanderborght, Basic Income (Harvard University Press, Cambridge, MA, 2017).

${ }^{84}$ The US experience in the mid-twentieth century seems to belie the argument that high taxes lead to poor economic growth; see S Pizzigati, The Rich Don't Always Win: The Forgotten Triumph over Plutocracy that Created the American Middle Class (Seven Stories Press, New York, NY, 2012) 5. Some of the twenty-first century circumstances, especially the degree of globalisation, might require a globally coordinated effort for ideas like a tax on capital to work. 
With respect to education, although a right to primary - and increasingly secondary, education is usually seen as a fundamental right within the liberal tradition, it is university education that has consistently proven to be the most important factor in social mobility. ${ }^{85}$ Article 13(2)(c) of the International Covenant on Economic, Social and Cultural Rights says that 'Higher education shall be made equally accessible to all, on the basis of capacity, by every appropriate means, and in particular by the progressive introduction of free education.' Social mobility solutions are often derided as missing the point - after all, they do not get rid of economic classes, rather they merely permit some members of one class to move into another. While this is true, a good deal of social mobility achieved through (say) universal tertiary education should reduce the gap between the very wealthy and the very poor, and therefore still serve the egalitarian goals this article is interested in. It is about time, therefore, that the practice of liberal constitutionalism began realising the promise of universally accessible and free higher education as a constitutionally guaranteed right.

Egalitarian political directives. So far, we have considered the possibility of incorporating the egalitarian principle as a preambular norm and a judicial norm. A third - compatible - possibility is the inclusion of the norm as a politically enforceable constitutional directive, contained in several state constitutions. ${ }^{86}$ A typical example of such directives is Article $38(2)$ of the Constitution of India:

The State shall, in particular, strive to minimize the inequalities in income, and endeavor to eliminate inequalities in status, facilities and opportunities, not only amongst individuals but also amongst groups of people residing in different areas or engaged in different vocations. ${ }^{87}$

Many liberal constitutions contain similar provisions, even if they do not explicitly identify them as 'directives'. Section 36 of the Canadian Constitution Act of 1982, which commits the political organs of the state

85 Piketty (n 56) 21; Milanović (n 41).

86 See Constitution of Bangladesh (1972) arts 14, 19; Constitution of Bhutan (2008) art 9; Constitution of Ethiopia (1995) art 89(2); Constitution of India (1950) art 38; Constitution of Ireland (1937) art 45(2); Constitution of Nepal (1990) art 25; Constitution of Nepal (2015) art 51; Nepal (interim constitution, 2007, art 34 and 35); Constitution of Nigeria (1979); Constitution of Nigeria (1999) art 16; Constitution of South Sudan (2011) art 37; Constitution of Sri Lanka (1978) art 27; Constitution of Tanzania (1977) art 9(j); Constitution of Thailand (1997) art 83; Qatar (provisional constitution, 1970, art 7).

87 Some Indian founders saw these egalitarian directives as necessary to achieve 'economic democracy' alongside political democracy. See generally U Bhatia (ed), The Indian Constituent Assembly: Deliberations on Democracy (Routledge, Oxford, 2018). 
to 'promoting equal opportunities for the well-being of Canadians' and 'furthering economic development to reduce disparity in opportunities' may be one of them. ${ }^{88}$

Constitutional directives are mandatory constitutional obligations imposed primarily on the political organs of the state to programmatically realise certain moral objectives. ${ }^{89}$ They are conceptually distinct from rights in that their breach cannot, on its own, give rise to a cause of action before any court - although they may be relied upon by courts as interpretive aids. ${ }^{90}$ These egalitarian directives tend to be very flexible, and - for the same reason - lack transparency. As they are addressed to the political state, they do not give rise to the counter-majoritarian difficulty.

It is, no doubt, possible to supplement these flexible, and overbroad, egalitarian directives with more specific directives that identify particular egalitarian goals necessary in a given context. For example, constitutions could learn from German ordoliberals of the post-Second World War era to mandate a robust framework of antitrust and anti-monopoly legislation that prevents the concentration of corporate wealth - one of the key drivers of material inequality. ${ }^{91}$ Similar directives could require land redistribution to approximate to the Rawlsian ideal of a propertyowing democracy, where wealth is dispersed widely rather than concentrated in a few.

While the absence of direct judicial enforcement has given rise to consistent worries about their effectiveness, newer constitutions are experimenting with increasingly sophisticated mechanisms to ensure that political actors cannot ignore their constitutional obligations. For example, section 162 of the Thai Constitution of 2017 requires that 'The Council of Ministers which will assume the administration of State affairs must, within fifteen days as from the date it takes office, state its policies to the National Assembly, which must be consistent with ... directive principles.' Similarly, Articles 53 and 54 of the Nepali Constitution of 2015 require the government to present

88 On section 36 generally, see HL Kong, 'The Spending Power in Canada' in P Oliver, P Macklem and N des Rosiers (eds), The Oxford Handbook of the Canadian Constitution (Oxford University Press, New York, NY, 2017) 433, 441ff; A Nader, 'Providing Essential Services: Canada's Constitutional Commitment under Section 36' (1996) 19(2) Dalhousie Law Journal 306; L Sossin, Boundaries of Judicial Review: The Law of Justiciability in Canada (Carswell, Toronto, 1999) 19.

89 T Khaitan, 'Directive Principles and the Expressive Accommodation of Ideological Dissenters' (2018) 16(2) International Journal of Constitutional Law 389.

90 On judicial uses of directives, see Khaitan (n 60) 629ff.

91 G Amato, Antitrust and the Bounds of Power: The Dilemma of Liberal Democracy in the History of the Market (Hart Publishing, Oxford, 1997); P Baeke and O Peschau, 'The Law and Policy of Competition in Germany' in G Majone (ed), Regulating Europe (Routledge, London, 1996) 94. 
an annual report on the progressive implementation of the directives, which is monitored by a parliamentary committee. ${ }^{92}$

Constitutions could build upon these experiments to give more teeth to egalitarian directives. They could, for example, mandate that the finance minister must forecast the likely impact of her state budget on the 20/20 ratio (like she typically does for the Gross Domestic Product), and that an equality regulator and a legislative committee audit the budget for its impact on inequality (like financial and monetary regulators often do vis-à-vis the GDP). Recent research has convincingly shown that beyond a certain threshold level of national income, levels of material inequality in a society are a much better predictor of well-being and human flourishing than GDP levels in any case. ${ }^{93}$ Constitutions could therefore take measures to raise the political salience of inequality indicators to the same level that GDP currently enjoys in economic policy and planning. They could create a separate 'Minister of Equality' with a clear and specific mandate to implement egalitarian and anti-plutocratic norms. They could also incorporate measures like section 19 of the UK Human Rights Act, requiring a minister to make a statement while introducing any Bill on its likely impact on equality metrics like the income quintile ratio.

Fourth branch regulation. Finally, dedicated 'fourth branch' institutions constitutionally empowered to implement key directives, in concert with other political and judicial branches - is also a possibility. ${ }^{94}$ Modelled on electoral commissions, central banks, and other constitutional or quasiconstitutional bodies, an independent Equality Commission could be tasked with implementing the general equality directive, whereas welldesigned antitrust and land reform commissions could be entrusted with more specific tasks. Many liberal jurisdictions already have such bodies constituted under statutes - their entrenchment as constitutional bodies could give them greater insulation from the power of the wealthy as they go about promoting equality.

All four sets of egalitarian solutions discussed above broadly respect the constraints of liberal constitutionalism. Different contexts will no doubt require various tweaks and experiments to suit local realities. At a general level, however, they do not pose serious conceptual or normative difficulties of the sort that might make them unacceptable to a liberal constitutionalist.

\footnotetext{
92 See also Ghana Constitution, art 34.

93 Wilkinson and Pickett (n 48).

94 See (n 104) for discussion on 'fourth branch' institutions.
} 


\section{Anti-plutocratic solutions: Protecting politics from money}

This section seeks to find answers to MacCormick's key challenge: 'what institutions will prevent wealthy citizens from dominating a government that is supposed to serve the entire citizenry?'95 While egalitarian solutions sought to tackle inequality itself, anti-plutocratic solutions seek to limit the influence of material power in politics. This anti-plutocratic sensibility is implicit in the basic liberal norm that guarantees fair political opportunity to all members of a political community. Given moral and political equality of persons, we know that a distribution of political opportunities is fair only if it isn't grossly unequal. We have also seen that, given the convertibility, subtlety, and resilience of power, formal political equality falls way short of ensuring fair political opportunity in most liberal societies. Even so, the right to political opportunity in international law and most domestic constitutions tends to be restricted to formal equality of vote, formally equal right to political participation and running for office, and a largely procedural conception of free and fair elections. ${ }^{96}$ These guarantees are no doubt essential, and routinely breached even in consolidated democracies the use of identity cards to disenfranchise black voters in the United States is a case in point. ${ }^{97}$ Even so, an interpretive development of legal doctrine on the right to fair political opportunity beyond a formal and procedural understanding to a real and substantive one - akin to the development of the scope of the right against discrimination from direct discrimination to indirect discrimination ${ }^{98}$ - is long overdue. At the very least, a robust proof of an effective political lockout of a group should merit at least a weak-form judicial intervention. Such a development will bring liberal constitutional practice closer to the normative promises of liberalism. There are already some signs of this substantive turn in certain jurisdictions, for example in the following opinion by Lady Hale, a British judge:

... in the United States of America ... Enormous sums are spent, and therefore have to be raised, at election times: it is estimated that the disputed 2000 elections for President and Congress cost as much as US $\$ 3$ billion. Attempts to regulate campaign spending are struck down

95 JP McCormick, Machiavellian Democracy (Cambridge University Press, Cambridge, 2011) 1.

96 See generally International Covenant on Civil and Political Rights, adopted 16 December 1966, GA Res 2200 (XXI), UN GAOR, 21st Sess, 999 UNTS 171, art 25; G H Fox, 'The Right to Political Participation in International Law' (1992) 17(2) Yale Journal of International Law 539.

97 Z Hajnal et al., 'Voter Identification Laws and the Suppression of Minority Votes' (2017) 79(2) The Journal of Politics 363.

98 T Khaitan, 'Indirect Discrimination' in K Lippert-Rasmussen (ed), The Routledge Handbook of the Ethics of Discrimination (Routledge, London, 2017) 30. 
in the name of the First Amendment ... A fortiori there is no limit to the amount that pressure groups can spend on getting their message across in the most powerful and pervasive media available.

In the United Kingdom, and elsewhere in Europe, we do not want our government or its policies to be decided by the highest spenders. Our democracy is based upon more than one person one vote. It is based on the view that each person has equal value. "Within the sphere of democratic politics, we confront each other as moral equals'... We have to accept that some people have greater resources than others with which to put their views across. But we want to avoid the grosser distortions which unrestricted access to the broadcast media will bring. ${ }^{99}$

Preambular commitment against plutocracy. This opinion contains the seeds for generating a full-fledged account of anti-plutocratic solutions. First, in the very least, a liberal constitution should not stand in the way of legal measures to check the role of money in politics. If it does so, it undermines liberalism itself. A preambular affirmation of the antiplutocratic norm should help orient the constitutional infrastructure to nudge courts to be more deferential to political attempts to rein in plutocracy, rather than resist them on maximalist understandings of liberal freedoms relating to speech, business, association, and property. The precise formula such a preambular norm should take will need to be worked out. 'Fair political opportunity' is a good start, but may need further elaboration to ensure it is read substantively.

Judicial possibilities. Secondly, a liberal constitution can, and should, do a lot more towards the enforcement of the anti-plutocratic norm, beyond simply getting out of its way. Realising fair political opportunity under an anti-plutocratic regime will require co-ordinated and sustained action on multiple fronts. Power is, well, powerful, and defeating it is not an easy task. Therefore, apart from enshrining anti-plutocracy as a preambular value, a judicially enforceable right to fair political opportunity should also be guaranteed. ${ }^{100}$

The biggest objection to such development arises from a now familiar worry - a judicially enforceable right to fair political opportunity will have the benefit of flexibility, but it will score low on transparency and

${ }_{99} R$ (on the application of Animal Defenders International) v. Secretary of State for Culture, Media and Sport, [2008] 1 AC 13121353 [47]-[48] (emphasis added).

100 Some courts already recognise such a right or interest, although they do not necessarily go as far as its scope would permit: Harper $v$ Canada (Attorney General), [2004] 1 S.C.R. 827 (Canada); McCloy v NSW, (2015) 257 CLR 178 (Australia); Gupta v Chawla, AIR 1975 SC 308 (India). 
polycentricity counts. Interestingly, the counter-majoritarian difficulty that often plagues judicial work will be less pronounced - at least on some accounts of legitimate judicial role, uncluttering the political process to ensure that no group is permanently excluded from political power is the main, if not the only, proper function of a constitutional court. ${ }^{101}$ If I am right in claiming that the very poor are in danger of more or less permanent exclusion from the political process under certain types of liberal regimes, courts will be justified in stepping in.

This still leaves the transparency and polycentricity worries. As with social rights, and the proposed right to material equality in the preceding sub-section, a limited judicial approach to a right to fair political opportunity - one that is sensitive to the limits of judicial expertise in dealing with complex polycentric issues - is viable, and analogous to other developments in some liberal states. As I have already alluded to, this right must go beyond a formal equality of vote, to include a substantive right to fair political opportunity. ${ }^{102}$ Much can be learnt from the judicial invention of the concept of indirect discrimination ('disparate impact', in the US) after the limitations of a more formal direct discrimination analysis became apparent. Liberal courts have become adept at examining the actual impact of a measure on a protected group, whether or not the intention of the decision-maker was discriminatory. ${ }^{103}$ A similar effect-based analysis could ask whether a particular act disproportionately excludes the relative poor from the political process - if it does, it will be presumptively unconstitutional, unless saved by weighty competing public interests. In some ways, the motivation behind this proposal is to achieve for the relative poor what the US Voting Rights Act 1965 sought to achieve for black people - but, and this is important, not just in relation to voting, but for all forms of political opportunities, including running for office, influencing political decisions and discourse, accessing political representatives and so on.

Role for political and fourth branch institutions. Needless to say, courts alone cannot enforce the anti-plutocratic norm. This is why the third

101 Ely (n 15)

102 Some scholars are beginning to even challenge one-person-one-vote as unjust, and are recommending weighted vote shares, based on the proportion of interests at stake: P Moraro, 'Younger Citizens Should Have More Votes than Those over 60' Sydney Morning Herald (6 July 2016) <https://www.smh.com.au/opinion/younger-citizens-should-be-allowed-morevotes-than-those-over-60-20160706-gpzq69.html>. A more feasible weighting system, at least in asymmetric federal contexts, would allocate state representation in federal legislatures after taking regional material disparities into account.

103 Khaitan (n 98). 
complementary solution to deal with the threat of plutocracy must engage non-judicial branches too. As with the egalitarian norm, courts will need support from political organs of the state as well as independent constitutional institutions (sometimes called the 'fourth branch'), ${ }^{104}$ like anti-corruption watchdogs and election commissions. This is precisely why framers should seek to constitutionalise the anti-plutocratic norm not just as an enforceable fundamental right and a preambular value, but also as a political directive (again, just like the egalitarian norm).

Apart from a general directive to preserve the autonomy of politics from the undue influence of wealth, a liberal constitution should also oblige political and fourth branch institutions more specifically to regulate campaign finance, political lobbying, and corruption in order to limit the direct role of money in politics. Constitutional institutions could also be obliged to prevent plutocratic capture of political discourse by promoting and strengthening public/cooperative/not-for-profit models of ownership and control in key discursive industries such as media, education, and NGOs. ${ }^{105}$ Basically, these knowledge-generating industries need to be made autonomous both from political as well as economic power. Needless to say, all such regulation must satisfy proportionality requirements so that the liberal guarantee of free speech is not unduly restricted. Content-neutral structural regulation that seeks inclusive, pluralistic, and democratic forms of ownership and control is most likely to satisfy proportionality requirements.

Furthermore, in our world today, economic power chiefly manifests itself through the agency of large, for-profit, corporations. Constitutions could lend their authority to the agenda of corporate reform and workplace democracy, to make employees meaningful participants, alongside shareholders and management, in the decision-making processes of all corporations. There are independent, and very good, reasons for constitutionalising workplace democracy in any case. ${ }^{106}$ But given the respective class make-up of employees vis-à-vis that of the management in a typical large corporation today, a genuine employee-voice in decision-

104 On fourth branch, see generally B Ackerman, 'The New Separation of Powers' (2000) 113(3) Harvard Law Review 633; C Fombad, 'The Diffusion of South-African Style Institutions? A Study in Comparative Constitutionalism' in R Dixon and T Roux (eds), Constitutional Triumphs, Constitutional Disappointments: A Critical Assessment of The 1996 South African Constitution's Local and International Influence (Cambridge University Press, Cambridge, 2018) 359; AJ Brown, 'The Integrity Branch: A “System", an "Industry", or a Sensible Emerging Fourth Arm of Government?' in M Groves (ed), Modern Administrative Law In Australia: Concepts And Context (Cambridge University Press, New York, NY, 2014) 301.

105 T Khaitan, 'Executive Aggrandizement in Established Democracies: A Crisis of Liberal Democratic Constitutionalism' (2019) 17(1) International Journal of Constitutional Law 342, 349. 106 Sempill (n 74). 
making could help break the corporation-plutocratic nexus, and its deleterious effects on democracy. ${ }^{107}$ In particular, as Piketty shows, the wide margin between the income of top earners and the rest of the labour force is a key driver of inequality in our society. ${ }^{108}$ Workplace democracy would change the system where managers effectively fix their own salaries, and could help reduce this margin.

A duty to vote: Fourthly, there are reasons to think that a compulsory voting system, as in Australia, helps to contain plutocracy. Since it is the poor who frequently tend to be excluded from political participation, a change from the right to vote to a compulsory voting system where all citizens have an obligation to vote is more likely to ensure that their franchise is exercised (and that the powerful find it harder to devise ways of disenfranchising them). ${ }^{109}$

Engine-room solutions. One difficulty with many of these solutions is the extreme resilience and adaptability of power to changing circumstances, so that the goal posts are constantly shifting. Issacharoff and Karlan characterise this as the Third Law of Political Motion: 'every reform effort to constrain political actors produces a corresponding series of reactions by those with power to hold on to it'. ${ }^{110}$ As long as gross material inequality, and therefore material power, continues to exist, the rich will continue to ensure that these regulations are rolled back or frustrated. This is precisely why anti-plutocratic solutions must be accompanied by egalitarian ones. But even the anti-plutocratic strategy could do more to ensure that politics keeps up with material power.

Instead of merely seeking to insulate political decision-making from material power, this final set of solutions seeks to directly guarantee a degree of political power to the relative poor. These solutions have been variously described as 'engine room'111 or 'class warfare'112 solutions.

107 On other suggestions for a structural reorganisation of the financial sector, see Sitaraman (n 5) 288-93.

108 Piketty (n 56).

109 A Lijphart, 'Unequal Participation: Democracy's Unresolved Dilemma' (1997) 91(1) The American Political Science Review 1; L Hill, 'Compulsory Voting and the Promotion of Human Rights in Australia' (2017) 23(2) Australian Journal of Human Rights 188; L Hill, 'Voting Turnout, Equality, Liberty and Representation: Epistemic versus Procedural Democracy' (2016) 19(3) Critical Review of International Social and Political Philosophy 283.

110 S Issacharoff and PS Karlan, 'The Hydraulics of Campaign Finance Reform' (1999) 77 Texas Law Review 1705, 1705; see also E McGaughey, 'Fascism-Lite in America (or the Social Ideal of Donald Trump)' (2018) 7(2) British Journal of American Legal Studies 293.

111 R Gargarella, Latin American Constitutionalism (Oxford University Press, Oxford, 2013) 185; Cf. Sitaraman (n 5) $276 \mathrm{ff}$.

112 Sitaraman (n 5) 276. 
Just as liberal constitutions in deeply divided societies sometimes offer ethnocultural minorities worried about being locked out of power a guaranteed access to some form of political power, a similar regime could be worked out in relation to class as well. The office of the Tribune in Republican Rome is a possible example of this type of power-sharing arrangement for the poor. Ancient Greeks resisted plutocracy by randomising selection to political office by lottery and rotation. MacCormick recently proposed a similar tribunate for the United States, to be composed of citizens chosen by lot for a year, and with the power to veto one decision each of the other three political branches every year. ${ }^{113}$ Other forms of ethnocultural power-sharing which could potentially be replicated include legislative quotas (where a certain number of seats are set aside for members from the group in question), ${ }^{114}$ a dedicated ministry in the executive government to look after the interests of that group, ${ }^{115}$ and an advisory council made up of group members (which has a right to be consulted on all relevant matters before a decision is finalised). ${ }^{116}$

The difficulty with any representative solution with regard to class is this: political representatives of the poor, once elected to public office, are very soon likely to stop being poor themselves (although cultural and familial ties will remain). Furthermore, unlike racial or religious groups, the poor tend to be a relatively amorphous group, making it harder to design stable institutional set-ups. Further still, in ethnocultural powersharing arrangements, it is likely that the richer in the minority group end up in these representative positions anyway. Class representation, especially of the lowest economic group, is especially fraught because political engagement - when you are likely to be barely making ends meet, have no cultural, economic or social capital, probably have a poor education and little experience in civic participation - can seem like an unaffordable luxury, exacerbated by job insecurity in electoral politics. It is not surprising that even scholars and politicians concerned about plutocracy frequently speak of empowering the 'middle' class rather than those at the bottom of the class hierarchy. ${ }^{117}$ Unlike the middle or even the working classes, this lowest 20 per cent group is frequently unemployed or part of the precariat,

113 McCormick (n 95) Ch 7.

114 For example, quotas for Dalits (former 'untouchable' castes) in the Indian Parliament.

115 The Canadian Federal Government has a 'Department of Indian Affairs and Northern Development', overseen by two cabinet ministers in charge of the affairs concerning people of the First Nations. Article 164(1) of the Indian Constitution mandates the appointment of a Minister in charge of tribal welfare in certain states. Such ministries will count as a powersharing solution only if the Minister typically belongs to the relevant group.

116 This is a key demand by indigenous Australians in the Uluru Statement from the Heart.

117 For example, Sitaraman (n 5). 
and therefore not represented even by trade unions. In fact, in most societies, it is hard to think of any institution that can be said to be reliably representative of the interests of this group.

Despite these difficulties, two engine-room possibilities exist - first, ensuring some form of representation for the poor in at least the unelected state (i.e. the bureaucracy), and second, inviting organisations genuinely representing the poor into the engine room (at least in an advisory capacity). State power in all democracies is vested not just in elected representatives, but in a vast array of unelected actors, the largest of which is usually the bureaucracy. ${ }^{118}$ At least some of the difficulties associated with political insurance for the poor in electoral politics do not apply to representation in the bureaucracy. For example, given the job security that the bureaucracy provides, it might be more attractive to the poor compared to electoral politics. No doubt, prior capacity-building mechanisms - such as access to higher education - need to be in place. But beyond that, affirmative action schemes that would ensure some access to the very poor in the governance of their state could go some way in resisting plutocracy.

The second set of engine-room solutions demand engagement of the state with representative organisations. Encouraging the emergence of organisations that genuinely represent the interests of this class is perhaps a first step, before solutions inviting them into the engine room can be considered. A regulatory environment that facilitates and encourages non-governmental political associations, civil society organisations, and trade unions is also likely to deepen democratic controls over elected representatives. ${ }^{119}$ A start can be made with a consultative role for trade unions in continental European-style advisory bodies (with representation from government, trade unions and employers' associations) with a stronger egalitarian mandate. ${ }^{120}$ Even though trade unions do not necessarily represent the bottom 20 per cent, they are often the closest thing to an organised egalitarian pressure group that many societies have, and getting them into the engine room is a good first step. ${ }^{121}$ Where grass-roots organisations with a leadership drawn from the poor themselves and a proven track record already exist, they should also be given a seat on such

118 The Indian Constitution, for example, mandates quotas for 'lower' caste groups in legislatures and the bureaucracy. See generally, Indian Constitution, arts 16, 243D, 243T, 330 and 332.

119 Gargarella (n 19) 232.

120 P Katzenstein, Small States in World Markets: Industrial Policy in Europe (Cornell University Press, London, 1985).

121 Ewing, for example, recommends the setting up of a 'National Economic Forum in which government, capital and labour operate to negotiate and agree economic policy within a framework of social democratic objectives established by law': Ewing (n 12) 353. 
committees. ${ }^{122}$ Lessons can be learnt from this experiment to put in place a constitutional mechanism with adequate checks and balances to ensure that such a committee will (a) in fact represent the interests of the bottom 20 per cent, and (b) will be taken seriously in the political discourse.

No doubt, many other possibilities exist. Workable constitutional solutions emerge after considerable consultation and experimentation by practitioners. Many of these solutions are no doubt rough around the edges, but can be finessed over time given sufficient attention by scholars and constitutional actors.

\section{Conclusion}

The arguments of this article push back against the equation of liberalism with neoliberal capitalism. Contrary to the views of the pre-eminent prophet of liberal thought quoted in the epigraph to this article, ${ }^{123}$ many people (liberals and non-liberals alike) still believe that capitalism is not only compatible with liberalism, but may even be required by the latter's protection of private property. Although Rawls had ruled out both state socialism and (neoliberal as well as welfare) capitalism as incompatible with liberalism, he identified two different economic models as being most respectful of liberal guarantees: (i) liberal socialism, where economic power is dispersed among worker-run firms functioning in a competitive market, and (ii) propertyowning democracy, where background institutions ensure that ownership of wealth and capital are dispersed in society rather than concentrated in a few. ${ }^{124}$ These regimes are similar to welfare capitalism to the extent that they recognise a right to private property, but are different in being concerned with more than guaranteeing access to a basic minimum to all citizens. The goal of this article was to rediscover the key liberal commitment to political equality and its implications for the treatment of gross material inequality in the liberal constitutional discourse.

We have seen that fair political opportunity is a key precondition for the legitimacy of a regime in liberal thought. Given the convertibility, subtlety, and resilience of power, we learnt that gross material inequality - produced by neoliberal economic policies - effectively locks the poor out of power

122 An experiment along these lines took place in an ad hoc manner in India under the Manmohan Singh government 2004-2014, where a National Advisory Council was constituted to advise the government on important areas of policy.

123 See also, JS Mill, Autobiography (Longmans, Green, Reader and Dyer, London, 1873) 230-1; DE Miller, 'Mill's "Socialism"' (2003) 2(2) Politics, Philosophy and Economics 213; WA Edmundson, John Rawls: Reticent Socialist (Cambridge University Press, Cambridge, 2017).

124 Rawls (n 1) $135 \mathrm{ff}$. 
and converts a democracy into a plutocracy. Such lockout breaches the legitimacy constraint of a liberal constitutional democracy. This being a constitutional problem, it calls for the constitutionalisation of measures to promote egalitarianism and prevent plutocracy. The usual objections to a constitutional concern with gross inequality and plutocracy - based on transparency, counter-majoritarianism, and flexibility - are useful design instructions, but do not rule out constitutionalisation. Finally, we went on a whistle-stop tour of a whole panoply of constitutional measures - already familiar to or incrementally developed from liberal constitutional thought and practice - that could be marshalled to promote material equality and prevent plutocracy.

I have no illusions that these measures will suffice on their own. Globalisation has linked intra-country inequality with inter-country inequality. It is not even clear, in today's world, how much difference a lone nation can make to inequality within its borders, if the international globalised order remains unchanged. The arguments of this article are relevant not only to constitutional law, but also to international law. Why and how the international legal order should confront gross material inequality within and between countries should be high on the agenda of international law scholars, and supplement the role that domestic constitutional law can play in protecting democracy.

\section{Acknowledgements}

I am grateful to several colleagues, especially Mark Tushnet, Vicki Jackson, Cheryl Saunders, Alexander Somek, Joo-Cheong Tham, Jeff King, Fergal Davis, Nick Barber, Julian Sempill, Jacob Weinrib, Richard Holden, Patrick Emerton, Suzanne Killmister, Ewan McGaughey, Shaun McVeigh, Aradhya Sethia and two anonymous reviewers for helpful comments, and to Nabila Lucente and Nick Gillies for help with references. 